OPEN ACCESS

Edited by:

Carolina Escobar,

University of Castilla La Mancha, Spain

Reviewed by:

Yongmo Wang,

Huazhong Agricultural University,

China

Pablo Castillo,

CSIC, Spain

${ }^{*}$ Correspondence:

Bing Yang

yangbing@cib.ac.cn

Feng $\mathrm{Ge}$

gef@ioz.ac.cn

Specialty section:

This article was submitted to

Plant Microbe Interactions,

a section of the journal

Frontiers in Plant Science

Received: 08 October 2019

Accepted: 21 January 2020

Published: 19 February 2020

Citation:

Yang B, Chen Q, Liu X, Chen F,

Liang $Y$, Qiang W, He $L$ and Ge $F$ (2020) Effects of Pest Management

Practices on Soil Nematode

Abundance, Diversity, Metabolic

Footprint and Community

Composition Under Paddy Rice Fields.

Front. Plant Sci. 11:88.

doi: 10.3389/fp/s.2020.00088

\section{Effects of Pest Management Practices on Soil Nematode Abundance, Diversity, Metabolic Footprint and Community Composition Under Paddy Rice Fields}

\author{
Bing Yang ${ }^{1 *}$, Qunying Chen ${ }^{2}$, Xianghui Liu ${ }^{2}$, Fajun Chen ${ }^{3}$, Yuyong Liang ${ }^{4}$, Wei Qiang ${ }^{1,5}$, \\ Lulu $\mathrm{He}^{1,5}$ and Feng $\mathrm{Ge}^{2,6 *}$ \\ ${ }^{1}$ Key Laboratory of Mountain Ecological Restoration and Bioresource Utilization \& Ecological Restoration, Biodiversity \\ Conservation Key Laboratory of Sichuan Province, Chengdu Institute of Biology, Chinese Academy of Sciences, Chengdu, \\ China, ${ }^{2}$ State Key Laboratory of Integrated Management of Pest Insects and Rodents, Institute of Zoology, Chinese \\ Academy of Sciences, Beijing, China, ${ }^{3}$ College of Plant Protection, Nanjing Agricultural University, Nanjing, China, ${ }^{4}$ Institute \\ of Plant Protection, Jiangxi Academy of Agricultural Sciences, Nanchang, China, ${ }^{5}$ College of Life Sciences, University of \\ Chinese Academy of Sciences, Beijing, China, ${ }^{6}$ CAS Center for Excellence in Biotic Interactions, University of Chinese \\ Academy of Sciences, Beijing, China
}

The wide-scale adoption of transgenic crops has aroused public concern towards potential impacts to the ecological services of soil fauna, such as soil nematodes. However, few studies has examined whether the cultivation of transgenic rice would pose greater threats to soil nematode community and associated ecological functions than insecticides application. Moreover, what are determinants of soil nematode community in paddy fields remains unclear. During a 3-year field study, rhizosphere soil samples of transgenic-Bt rice, its counterpart non-Bt parental rice and not-Bt rice with insecticides application were taken at four times in the rice developmental cycle using a random block design with three replications for each treatment. We hypothesized that the effects of pest management practice on soil nematode abundance and metabolic footprint change with trophic group and sampling time. We also predicted there were significant differences in structure and composition of soil nematode community across the three treatments examined and sampling times. In agreement with our expectation, the effects of pest management practice on nematode abundance and metabolic footprints depend on trophic group and sampling time. However, pest management practice exerted no apparent effect on nematode diversity and community composition. Soil nutrient availability and C:N molar ratio are the primary regulating factor of soil nematode community in rice paddy fields. In conclusion, our findings implied that changes in abundance, diversity, metabolic footprints associated with the crop growth stage overweighed the application of $B t$ rice and insecticides. The cultivation of $B t$ rice Huahui-1 exerted no measurable adverse effect on soil nematode community in rhizosphere soil over 3 years of rice cropping.

Keywords: soil nematode community, management practice, Bt rice cultivation, insecticides application, paddy field 


\section{INTRODUCTION}

As an important cereal crop worldwide, rice (Oryza sativa L.) provides staple food and nutrition for about $50 \%$ of the global population (Lu and Snow, 2005). However, the yield of rice in China suffers severe losses mainly from four major lepidopteran pests, namely, the rice striped stem borer Chilo suppressalis (Crambidae), the yellow stem borer Scirpophaga incertulas (Crambidae), the pink stem borer Sesamia inferens (Noctuidae) and the rice leaf roller Cnaphalocrocis medinalis (Crambidae) (Chen et al., 2011). To reduce the yield loss resulting from pest damage, China devoted great effort in developing insect-resistant rice using transgenic technology and has developed multiple $B t$ rice lines (Chen et al., 2011). Empirical evidence supported $B t$ rice can result in an evidently decreased application of pesticides, and thus benefit human health and the environment (Huang et al., 2005; Chen et al., 2011). However, the Cry1 Ab/Ac protein, which was continuously produced within plant tissue of $B t$-rice, could be released through root exudates during growth and persistent in the rhizosphere in paddy soils (Wang et al., 2018). Therefore, it might affect the activity, structure, diversity of soil fauna, and interactions among components of soil food webs, which in turn would influence soil fertility and plant productivity. Accordingly, there is a pressing need to understand the impacts of $B t$ rice on the sustainability of agricultural ecosystem.

Nematodes play a pivotal role in ecosystem functions because they hold a central role in soil food webs and actively participate in ecological processes, such as decomposition, nutrient cycling, and pest suppression (Neher, 2010). Moreover, they react rapidly to disturbances and enrichment (Bongers, 1999). Therefore, the abundance and community composition of soil nematode have been commonly used to indicate soil health condition and soil functions (Bongers and Ferris, 1999; Neher, 2001). Ample available evidence support that soil nematodes are related to soil physicochemical properties (Briar et al., 2011; Godefroid et al., 2013), microorganisms (Kaplan and Noe, 1993), management practice (Biederman et al., 2008; Neher, 2010; Naira and Ngouajiob, 2012; Liu et al., 2016), and stochastic factors. The frequency of pesticide application in fields of $B t$ rice is lower than that of its counterpart non-Bt rice (Li et al., 2014). However, the $C r y 1 A b / A c$ of $B t$ rice can enter soil ecosystems through root exudations, pollen and plant residue inputs, and thus nematodes are likely to be exposed to bioactive proteins from transgenic $B t$ rice because of their trophic position in soil food webs (Ruf et al., 2013). Moreover, the Cry $1 \mathrm{Ab} / \mathrm{Ac}$ proteins of Bt rice might accumulate in rhizosphere soil (Liu et al., 2018a). However, no definite conclusions have been drawn about whether $B t$ rice can negatively affect soil nematode. Besides, there are compounding factors affecting the persistence and accumulation of Bt-toxins, and the activity, persistence, and accumulation of $B t$ protein would vary with Bt toxin origin, plant species, and environment condition (Icoz and Stotzky, 2008; Chen et al., 2017a). For example, the activity and persistence of the insecticidal protein varies depending on climatic conditions (Zwahlen et al., 2003) and soil properties (Tapp et al., 1994; Saxena et al., 1999). Thus, whether Bt rice cultivation would affect soil nematodes and associated ecosystem functioning remains elusive, particularly under paddy field condition.
The primary objectives of this study were: 1 ) to quantify the effects of contrasting pest management practices on soil quality with soil nematode community as integrative bio-indicator in rice soil under paddy field condition; and 2) to explore the main driving force of soil nematode community in paddy fields. We also hypothesized that the effect size of $B t$ rice cultivation on soil nematode abundance and metabolic footprints changes with trophic group and plant developmental stage (exactly sampling time), because the interaction strength between plant and soil nematodes might vary with trophic group and the microclimate as well as the quantity and quality of plant detritus entering soils might vary with plant phenology. We also hypothesized that the impact of pesticides application on abundance, diversity, and footprints of soil nematode community would be greater than that of $B t$ rice cultivation, since pesticides are of broad spectrum whereas the toxicity of $B t$ rice is specific to target insects.

\section{MATERIALS AND METHODS}

\section{Site Description}

A 3-year field experiment was carried out at the Jiangxi Academy of Agricultural Sciences, Jiangxi province (N28 $21^{\prime} 91.4^{\prime \prime}$, E115 $55^{\prime} 49.7^{\prime \prime}$ ), where the research of transgenic plants is permitted. The mean annual temperature and the mean annual rainfall of this region were $17.6^{\circ} \mathrm{C}$ and $1,624.4 \mathrm{~mm}$, respectively. The soil here is loamy sand, and the physicochemical properties of the field soils were as follows: total soil organic carbon (SOC), 21.79 $\mathrm{g} / \mathrm{kg}$; total nitrogen (TN), $1.17 \mathrm{~g} / \mathrm{kg}$; total phosphorous (TP), 0.84 $\mathrm{g} / \mathrm{kg}$; total potassium (TK), $21.01 \mathrm{~g} / \mathrm{kg}$; available nitrogen (AN), $84.82 \mathrm{mg} / \mathrm{kg}$; available phosphorous (AP), $5.82 \mathrm{mg} / \mathrm{kg}$; and available potassium (AK), $49.17 \mathrm{mg} / \mathrm{kg}$.

\section{Plant Materials}

The transgenic Bt rice line (Huahui-1) and its corresponding non-transgenic counterparts (Minghui-63), which were provided by Huazhong Agricultural University, Wuhan, China were used in this experiment. The Huahui- 1 is a certificate-granted insectresistant rice line, it contains a fused $c r y 1 A b / 1 A c$ gene under the control of the rice actinI promoter showing a high level of expression of the $\delta$-endotoxin, and thus is highly resistant to target insects under controlled conditions (Tu et al., 2000); while Minghui-63 is an elite Indica cytoplasmic male sterile restorer line developed in China in the early 1980s from the IR-30×Gui630 hybrid combination.

\section{Experimental Design}

The experiment was conducted using a randomized block design with three treatments including $B t$ rice, non-Bt with normal pesticide application, and non-Bt rice without pesticide application. For each treatment, there were three replications. Seeds were sown in mid-May, and seedlings were transplanted in mid-June in 2012, 2013, and 2014. The distance between rice seedlings was approximately $30 \mathrm{~cm}$, which is commonly used in fields by farmers in this region. Rice was cultivated using standardized agricultural management practices except for pesticide application during the growing season. Weeds were 
controlled by hand-weeding every 3 weeks. The pests in $B t$ rice and one non-Bt fields were trapped by yellow sticky traps, whereas another non-Bt fields was controlled with insecticides spray.

\section{Soil Sampling and Analysis}

Soil samples were collected on June 11, August 11, September 11, and October 11 of 2012, 2013, and 2014 at the seedling, booting, heading, and maturing stage of rice. We also took soil samples on April 11 of 2013, 2014, and 2015 corresponding to prophase of sowing. Before each sampling time, the flood irrigation was stopped for 3 days. In each plot, eight soil cores $(2.5 \mathrm{~cm}$ in diameter) were collected randomly between rice rows, mixed thoroughly and pooled as a composite sample. The samples were placed in plastic bags and stored in a portable cooler for transport to the laboratory. Each soil sample was divided into two subsamples of equal volume. One was passed through a 2$\mathrm{mm}$ sieve to remove root fragments and other organic debris in soil and stored at $4^{\circ} \mathrm{C}$ before testing. This subsample was used to determine soil water content (SWC) and soil nematode community. The other subsample was air-dried and sieved before using for the analysis of SOC and other soil properties including TN, TP, AN, AP, and AK.

Nematodes were extracted from $100 \mathrm{~g}$ of field-moisture soil from each subsample using the minor modified cotton-wool filter method depending on the nematode mobility (Liang et al., 2009) with three technical replicates for each sample within 1 week after sampling. After a $48 \mathrm{~h}$ of extraction, nematodes were killed through heating, and thus fixed and preserved in $4 \%$ formaldehyde. Subsequently, $10 \%$ of the individuals (but not less than 200 individuals, if possible) were additionally identified to genus level based on nematode morphology of the stoma, stylet, basal bulb, and teeth characteristics following Bongers (1994) and Ahmad and Jairajpuri (2010) at a $400 \times$ or $1,000 \times$ magnification. When the individual number of nematodes in a sample was less than 200, all the specimens were identified. All identified specimens were assigned into bacterial feeders, fungal feeders, plant feeders, omnivores and predators (Yeates et al., 1993), and c-p classes (Bongers and Bongers, 1998).

SOC content was measured using the hot oxidation with potassium dichromate and sulfuric acid (Yeomans and Bremner, 1988). Soil TN was determined by the semimicro-Kjeldahl method after soil was digested by $\mathrm{HClO}_{4}$ and HF. The contents of TP, TK, $\mathrm{AK}$, and AP were assayed using inductively coupled plasma mass spectrometry (ICP-MS) analysis (IRIS Intrepid II XSP system; Thermo Electric Co., USA). The content of TP in soil was digested with $\mathrm{H}_{2} \mathrm{SO}_{4}-\mathrm{HClO} 4$ solution at $250^{\circ} \mathrm{C}$ and determined by the molybdenum-blue colorimetric method (Walker and Adams, 1958). The content of soil AP was extracted with $0.5 \mathrm{M}$ $\mathrm{NaHCO}_{3}$ solution and determined by the molybdenum-blue colorimetric method (Olsen and Sommers, 1982).

\section{Statistical Analysis}

The effect of pest management practice on abundance of soil nematodes was examined with generalized linear models, whereas that on diversity and metabolic footprints of soil nematode community was examined with general linear models. Subsequently, differences in composition of soil nematodes communities among treatments were investigated with nonmetric multidimensional scaling (NMDS). Additionally, statistical differences in nematode community composition within plots of contrasting management practices and sampling times were assessed with "adonis" function based on 9,999 restricted permutations of the data. Finally, environmental variables which are related to the ordination of NMDS were selected with "envfit" function in vegan packages. The multivariate analyses including NMDS, adonis, and envfit, were performed with the "MASS" and the "vegan" package in $R$ version 3.3.1 ( $R, 2016)$.

\section{RESULTS}

\section{Abundance of Soil Nematodes}

In 2012 and 2013, pest management practice exerts significant effects on abundances of all trophic groups and total nematode abundance (Table 1). In 2014, pest management practice exerts significant effects on the abundances of bacterivores (Wald $\chi^{2}=$ 10.466, $P=0.005$ ), omnivores (Wald $\chi^{2}=35.613, P<0.001$ ), and total nematode abundance (Wald $\chi^{2}=15.847, P<0.001$ ), whereas negligible effect on abundances of other trophic groups (Table 1). Specifically, the pesticide application greatly reduced nematode abundance, whereas $B t$ rice did not. Additionally, nematode abundances of the non-Bt rice fields with pesticides application were significantly lower in comparison with those of $B t$ rice fields. However, there were significant interactive effects of management ${ }^{\star}$ sampling time, suggesting the effect of pest management practice on nematode abundance depended on sampling time.

\section{Diversity of Soil Nematode Community}

Pest management practice was found be of no significant effect on the taxa richness, Margalef richness index, Shannon-Weaver diversity index, Simpson dominance index, and Pielou evenness index of soil nematode community (Table 2). The diversity indices vary greatly across sampling times, but they are independent of management practice.

\section{Metabolic Footprints of Soil Nematodes}

The effects of management practice on metabolic footprints of soil nematodes vary depending on year and trophic group examined. In 2012, no detectable difference in metabolic footprints examined among contrasting management practices of rice was observed. In 2013, herbivore footprint and predator footprint changed with management practice. In 2014, management practice exerted a significant effect on composite footprint, structure footprint, bacterivore footprint and omnivore footprint of soil nematode community. Additionally, metabolic footprints of soil nematodes varied with sampling time in most cases. However, the effects of management practice on metabolic footprints did not change with sampling time in most cases (Table 3).

\section{Determinant of Soil Nematode Community in Paddy Fields}

The nematode taxa richness in soils of rice paddy fields in the 2012, 2013 and 2014 growing season was 25, 21, and 22, 
TABLE 1 | Summary of generalized linear models testing the effects of management practice, sampling time, and their interaction on abundance of soil nematodes in rice fields of contrasting management practices during 2012-2014 growing seasons.

\begin{tabular}{|c|c|c|c|c|c|}
\hline Year & Variable & Parameter & Management & Sampling time & Interaction \\
\hline & All & $d f$ & 2 & 3 & 6 \\
\hline \multirow[t]{12}{*}{2012} & Herbivores & Wald $\chi^{2}$ & 52.651 & $1,280.983$ & 31.362 \\
\hline & & $P^{n}$ & $<0.001$ & $<0.001$ & $<0.001$ \\
\hline & Bacterivores & Wald $\chi^{2}$ & 5.487 & 579.862 & 98.021 \\
\hline & & $P$ & $<0.0064$ & $<0.001$ & $<0.001$ \\
\hline & Fungivores & Wald $\chi^{2}$ & 17.351 & 311.93 & 60.462 \\
\hline & & $P$ & $<0.001$ & $<0.001$ & $<0.001$ \\
\hline & Omnivores & Wald $\chi^{2}$ & 6.657 & 16.856 & 33.12 \\
\hline & & $P$ & 0.036 & 0.001 & $<0.001$ \\
\hline & Predators & Wald $\chi^{2}$ & 33.941 & 143.775 & 105.445 \\
\hline & & $P$ & $<0.001$ & $<0.001$ & $<0.001$ \\
\hline & Total & Wald $\chi^{2}$ & 139.497 & $1,262.296$ & 96.973 \\
\hline & & $P^{n}$ & $<0.001$ & $<0.001$ & $<0.001$ \\
\hline \multirow[t]{12}{*}{2013} & Herbivores & Wald $\chi^{2}$ & 95.563 & 254.174 & 25.206 \\
\hline & & $P$ & $<0.001$ & $<0.001$ & $<0.001$ \\
\hline & Bacterivores & Wald $\chi^{2}$ & 93.906 & 509.785 & 106.725 \\
\hline & & $P$ & $<0.001$ & $<0.001$ & $<0.001$ \\
\hline & Fungivores & Wald $\chi^{2}$ & 169.109 & 250.999 & 189.805 \\
\hline & & $P$ & $<0.001$ & $<0.001$ & $<0.001$ \\
\hline & Omnivores & Wald $\chi^{2}$ & 115.414 & 483.906 & 19.799 \\
\hline & & $P$ & $<0.001$ & $<0.001$ & 0.003 \\
\hline & Predators & Wald $\chi^{2}$ & 339.198 & $1,176.536$ & 51.586 \\
\hline & & $P$ & $<0.001$ & $<0.001$ & $<0.001$ \\
\hline & Total & Wald $\chi^{2}$ & 824.096 & $1,215.524$ & 109.763 \\
\hline & & $P$ & $<0.001$ & $<0.001$ & $<0.001$ \\
\hline \multirow[t]{12}{*}{2014} & Herbivores & Wald $\chi^{2}$ & 0.527 & 400.864 & 68.868 \\
\hline & & $P^{n}$ & 0.768 & $<0.001$ & $<0.001$ \\
\hline & Bacterivores & Wald $\chi^{2}$ & 10.466 & 274.138 & 21.468 \\
\hline & & $P$ & 0.005 & $<0.001$ & 0.002 \\
\hline & Fungivores & Wald $\chi^{2}$ & 5.156 & 785.646 & 15.91 \\
\hline & & $P$ & 0.076 & $<0.001$ & $<0.001$ \\
\hline & Omnivores & Wald $\chi^{2}$ & 35.613 & 848.327 & 49.619 \\
\hline & & $P$ & $<0.001$ & $<0.001$ & $<0.001$ \\
\hline & Predators & Wald $\chi^{2}$ & 2.541 & 297.212 & 86.6. \\
\hline & & $P$ & 0.281 & $<0.001$ & $<0.001$ \\
\hline & Total & Wald $\chi^{2}$ & 15.847 & $1,668.931$ & 155.559 \\
\hline & & $P$ & $<0.001$ & $<0.001$ & $<0.001$ \\
\hline
\end{tabular}

The bolded results indicate difference in variables across treatments are statistically significant ( $p$ value $<0.05$ ).

respectively (Appendix A). With exception of the 2013 growing season, sampling date $(P<0.05)$ rather than management practice $(P>0.05)$ affect community composition of soil nematodes (Table 4; Figure 1). In 2012, the community composition of soil nematodes in rice fields correlate with available nutrients (including available N, P, and $\mathrm{K}$ ), TN and TP in soils (Figure 2A). In 2013, the community composition of soil nematodes in rice fields correlate with available $\mathrm{N}, \mathrm{SOC}, \mathrm{TN}, \mathrm{TP}$, and C:N molar ratio in soils and soil microbial biomass (Figure 2B). In 2014, the community composition of soil nematodes in rice fields correlate with available $\mathrm{N}$, available $\mathrm{K}, \mathrm{SOC}, \mathrm{TN}, \mathrm{TP}$, and C:N molar ratio in soils and soil microbial biomass (Figure 2C).

\section{DISCUSSION}

The wide-scale adoption of $B t$ crops evidently reduces chemical insecticides application (Huang et al., 2005; Lu et al., 2012). However, $B t$ crops pose potential environmental risk to soil biota
TABLE 2 | Summary of general linear models testing the effects of management practice, sampling time, and their interaction on the diversity of soil nematode community in rice fields during 2012-2014 growing seasons.

\begin{tabular}{|c|c|c|c|c|c|c|c|c|c|c|}
\hline \multirow[t]{2}{*}{ Year } & \multirow[t]{2}{*}{ Variable } & \multicolumn{3}{|c|}{$\begin{array}{c}\text { Management } \\
\text { practice }\end{array}$} & \multicolumn{3}{|c|}{ Sampling time } & \multicolumn{3}{|c|}{ Interaction } \\
\hline & & $d f$ & $\boldsymbol{F}$ & $P$ & $d f$ & $\boldsymbol{F}$ & $P$ & $d f$ & $\boldsymbol{F}$ & $P$ \\
\hline \multirow[t]{5}{*}{2012} & $S$ & 2 & 1.353 & 0.277 & 3 & 8.885 & $<0.001$ & 6 & 0.480 & 0.817 \\
\hline & $\mathrm{SR}$ & 2 & 0.426 & 0.658 & 3 & 5.338 & 0.006 & 6 & 0.289 & 0.937 \\
\hline & $\mathrm{H}^{\prime}$ & 2 & 0.284 & 0.755 & 3 & 4.494 & 0.012 & 6 & 1.166 & 0.357 \\
\hline & $\lambda$ & 2 & 0.992 & 0.386 & 3 & 4.018 & 0.019 & 6 & 1.158 & 0.361 \\
\hline & J & 2 & 0.885 & 0.426 & 3 & 2.566 & 0.078 & 6 & 1.074 & 0.405 \\
\hline \multirow[t]{5}{*}{2013} & S & 2 & 0.553 & 0.582 & 3 & 4.573 & 0.011 & 6 & 0.482 & 0.815 \\
\hline & $\mathrm{SR}$ & 2 & 1.662 & 0.211 & 3 & 2.539 & 0.080 & 6 & 0.789 & 0.588 \\
\hline & $H^{\prime}$ & 2 & 0.386 & 0.684 & 3 & 4.409 & 0.013 & 6 & 0.386 & 0.881 \\
\hline & $\lambda$ & 2 & 0.340 & 0.715 & 3 & 2.758 & 0.064 & 6 & 0.435 & 0.848 \\
\hline & $J$ & 2 & 0.925 & 0.410 & 3 & 3.348 & 0.036 & 6 & 0.665 & 0.679 \\
\hline \multirow[t]{5}{*}{2014} & $S$ & 2 & 0.051 & 0.951 & 3 & 28.675 & $<0.001$ & 6 & 0.624 & 0.709 \\
\hline & SR & 2 & 0.107 & 0.899 & 3 & 13.517 & $<0.001$ & 6 & 0.568 & 0.751 \\
\hline & $\mathrm{H}^{\prime}$ & 2 & 0.019 & 0.982 & 3 & 18.867 & $<0.001$ & 6 & 0.418 & 0.860 \\
\hline & $\lambda$ & 2 & 0.096 & 0.909 & 3 & 14.538 & $<0.001$ & 6 & 0.498 & 0.804 \\
\hline & $J$ & 2 & 0.032 & 0.969 & 3 & 13.684 & $<0.001$ & 6 & 0.65 & 0.69 \\
\hline
\end{tabular}

$S$, taxa richness; SR, Margalef richness index; $H^{\prime}$, Shannon-Weaver diversity index; $\lambda$, Simpson dominance index; J, Pielou evenness index.

The bolded results indicate difference in variables across treatments are statistically significant ( $p$ value $<0.05$ ).

because they might change the quantity and quality of nutrient inputs and directly impact soil organisms with toxic activity of $B t$ protein. To date, whether the positive effects of the cultivation of $B t$ crop due to decreased application of chemical insecticides may outweigh its potential negative effects is unclear. Moreover, the responses of soil nematode to certain $B t$ transformation event was found to be context-specific, and thus a case-by-case study is necessary. China has developed multiple $B t$ rice lines to control target lepidopteran pests and boost agricultural productivity. For example, the Huahui- 1 has been granted bio-safety certificates by the Chinese authorities since 2009. However, it has not been allowed to enter the Chinese agricultural system due to public concern towards its potential adverse environmental effects and food safety. Therefore, to enhance the communication about science related issues of $B t$ rice to public maybe a promising alternative of the commercial production of $B t$ rice in near future. The present study utilized the scare opportunity to figure out the potential environmental risks of the Huahui-1 on agricultural ecosystem.

\section{No Apparent Impact of Bt Rice Cultivation on Soil Nematodes}

In contrast to most of available studies addressing potential environment risks of $B t$ corn or cotton on soil nematode community in terrestrial ecosystems (Manachini and Lozzia, 2002; Griffiths et al., 2005; Höss et al., 2011; Karuri et al., 2013; Li and Liu, 2013; Neher et al., 2014; Yang et al., 2014; Höss et al., 2015; Liu et al., 2015; Čerevková et al., 2017; Liu et al., 2018b), we evaluated those of $B t$ rice in aquatic ecosystem. Our study revealed no significant adverse effect of $B t$ rice cultivation on soil nematode communities under paddy field. Our results are in agreement with other studies suggesting that no impact of $B t$ crops cultivation on either soil nematodes (Manachini and Lozzia, 2002; Griffiths et al., 2005; Höss et al., 2011; Karuri et al., 2013; Li and Liu, 2013; Neher et al., 2014; 
TABLE 3 | Summary of general linear models testing the effects of management practice, sampling time and their interaction on the metabolic footprints of soil nematode community in rice fields during 2012-2014 growing seasons.

\begin{tabular}{|c|c|c|c|c|c|c|c|c|c|c|}
\hline \multirow[t]{2}{*}{ Year } & \multirow[t]{2}{*}{ Variable } & \multicolumn{3}{|c|}{ Management practice } & \multicolumn{3}{|c|}{ Sampling time } & \multicolumn{3}{|c|}{ Interaction } \\
\hline & & $d f$ & $\boldsymbol{F}$ & $P$ & $d f$ & $\boldsymbol{F}$ & $\boldsymbol{P}$ & $d f$ & $\boldsymbol{F}$ & $P$ \\
\hline \multirow[t]{8}{*}{2012} & CMF & 2 & 0.598 & 0.558 & 3 & 2.014 & 0.139 & 6 & 0.176 & 0.981 \\
\hline & EMF & 2 & 0.666 & 0.523 & 3 & 13.665 & $<0.001$ & 6 & 0.315 & 0.923 \\
\hline & SMF & 2 & 0.392 & 0.68 & 3 & 0.779 & 0.517 & 6 & 0.18 & 0.98 \\
\hline & HMF & 2 & 1.858 & 0.178 & 3 & 28.639 & $<0.001$ & 6 & 0.885 & 0.521 \\
\hline & FMF & 2 & 0.363 & 0.699 & 3 & 4.642 & 0.011 & 6 & 0.87 & 0.531 \\
\hline & BMF & 2 & 0.653 & 0.53 & 3 & 9.148 & $<0.001$ & 6 & 0.221 & 0.966 \\
\hline & PMF & 2 & 2.051 & 0.151 & 3 & 11.165 & $<0.001$ & 6 & 1.350 & 0.274 \\
\hline & OMF & 2 & 0.451 & 0.642 & 3 & 2.205 & 0.114 & 6 & 0.041 & 1.00 \\
\hline \multirow[t]{8}{*}{2013} & $\mathrm{CMF}$ & 2 & 2.479 & 0.105 & 3 & 5.797 & 0.004 & 6 & 0.224 & 0.965 \\
\hline & EMF & 2 & 2.010 & 0.156 & 3 & 2.856 & 0.058 & 6 & 1.099 & 0.392 \\
\hline & SMF & 2 & 2.381 & 0.114 & 3 & 6.301 & 0.003 & 6 & 0.236 & 0.96 \\
\hline & HMF & 2 & 4.366 & 0.024 & 3 & 7.869 & 0.001 & 6 & 0.550 & 0.765 \\
\hline & FMF & 2 & 3.004 & 0.069 & 3 & 2.940 & 0.054 & 6 & 1.098 & 0.392 \\
\hline & BMF & 2 & 1.948 & 0.164 & 3 & 3.612 & 0.028 & 6 & 0.894 & 0.515 \\
\hline & PMF & 2 & 3.864 & 0.035 & 3 & 7.91 & 0.001 & 6 & 0.684 & 0.665 \\
\hline & OMF & 2 & 1.471 & 0.25 & 3 & 4.82 & 0.009 & 6 & 0.113 & 0.994 \\
\hline \multirow[t]{8}{*}{2014} & CMF & 2 & 13.256 & $<0.001$ & 3 & 64.812 & $<0.001$ & 6 & 9.164 & $<0.001$ \\
\hline & EMF & 2 & 2.86 & 0.077 & 3 & 85.813 & $<0.001$ & 6 & 1.985 & 0.108 \\
\hline & SMF & 2 & 13.192 & $<0.001$ & 3 & 61.778 & $<0.001$ & 6 & 9.174 & $<0.001$ \\
\hline & HMF & 2 & 0.604 & 0.555 & 3 & 44.736 & $<0.001$ & 6 & 3.755 & 0.009 \\
\hline & FMF & 2 & 0.563 & 0.577 & 3 & 113.882 & $<0.001$ & 6 & 0.676 & 0.67 \\
\hline & $\mathrm{BMF}$ & 2 & 4.026 & 0.031 & 3 & 43.949 & $<0.001$ & 6 & 4.254 & 0.005 \\
\hline & PMF & 2 & 0.465 & 0.634 & 3 & 10.072 & $<0.001$ & 6 & 1.442 & 0.24 \\
\hline & OMF & 2 & 21.684 & $<0.001$ & 3 & 106.575 & $<0.001$ & 6 & 13.422 & $<0.001$ \\
\hline
\end{tabular}

BMF, bacterivore footprint; CMF, composite footprint; EMF, enrichment footprint; FMF, fungivore footprint; HMF, herbivore footprint; OMF, omnivore footprint; PMF, predator footprint; SMF, structure footprint.

The bolded results indicate difference in variables across treatments are statistically significant ( $p$ value $<0.05)$.

TABLE 4 | Similarity of soil nematode community in Bt rice field without insecticide application, non-Bt rice fields with and without insecticide application.

\begin{tabular}{llccc}
\hline Year & \multicolumn{1}{c}{ Source } & $\boldsymbol{d f}$ & $\boldsymbol{F}$ & $\boldsymbol{P}$ \\
\hline \multirow{2}{*}{2012} & Management practice & 2 & 1.02 & 0.399 \\
& Sampling time & 3 & 10.86 & $\mathbf{0 . 0 0 1}$ \\
& Interaction & 6 & 0.76 & 0.784 \\
\multirow{2}{*}{2013} & Management practice & 2 & 2.13 & $\mathbf{0 . 0 4 2}$ \\
& Sampling time & 3 & 4.93 & $\mathbf{0 . 0 0 1}$ \\
& Interaction & 6 & 0.48 & 0.988 \\
& Management practice & 2 & 1.53 & 0.168 \\
& Sampling time & 3 & 25.86 & $\mathbf{0 . 0 0 1}$ \\
& Interaction & 6 & 1.7 & $\mathbf{0 . 0 5 3}$
\end{tabular}

The bolded results indicate difference in variables across treatments are statistically significant ( $p$ value $<0.05$ ).

Yang et al., 2014; Höss et al., 2015; Liu et al., 2015; Chen et al., 2017a; Chen et al., 2017b; Liu et al., 2018b) or other aquatic fauna (Wang et al., 2013; Li et al., 2014; Wang et al., 2014). One possible interpretation is that the concentration of Cry protein in field soils is lower than the threshold value which is adverse to the reproduction and growth rate of soil nematodes. There are several reasons for the low Cry protein concentration in the rice paddy soil. On one hand, the concentration of Cry proteins that enter soils is relatively lower or it is diluted in water. On the other hand, Cry proteins may be readily degraded (Wang et al., 2007; Liu et al., 2018b). In a study with the same rice cultivar (Huahui-1), the authors suggest that Cry1Ab/Ac proteins could not be detected in irrigation water of the rhizotrons (Liu et al., 2018a).

\section{More Noticeable Change in Soil Nematodes Community With Time in Comparison With Application of Pesticides and $B t$ Rice}

In contrast to most of available studies, which only focused on the difference in parameters of soil nematode community between $B t$ and non-Bt corn or cotton (Manachini and Lozzia, 2002; Griffiths et al., 2005; Höss et al., 2011; Karuri et al., 2013; Li and Liu, 2013; Neher et al., 2014; Yang et al., 2014; Höss et al., 2015; Liu et al., 2015; Čerevková et al., 2017; Chen et al., 2017a; Chen et al., 2017b), we set up another treatment that is the not-Bt crop field with chemical pesticides application when necessary. This is necessary because non-Bt crop refuge has been proposed as a promising strategy for delaying the resistance development towards Bt crop (Gould, 2000; Tabashnik and Carriere, 2017). However, previous studies reported that planthoppers move from $B t$ to adjacent non-Bt rice fields (Chen et al. 2003a; Wang et al., 2018) and that fungal diseases and non-target pests still required to be controlled with pesticides application when full yield is expected to be achieved (Wang et al., 2010). This indicates even if the cultivation of $B t$ rice cultivation has a great potential to reduce the use of broad-spectrum chemical insecticides (High et al., 2004), pesticides application in Bt rice is still required. However, pesticide sprays is neither effective nor environment-friendly (Frutos et al., 1999). For example, one study demonstrates that pesticide application results in biodiversity loss in rice-based ecosystems (Halwart, 2008). 


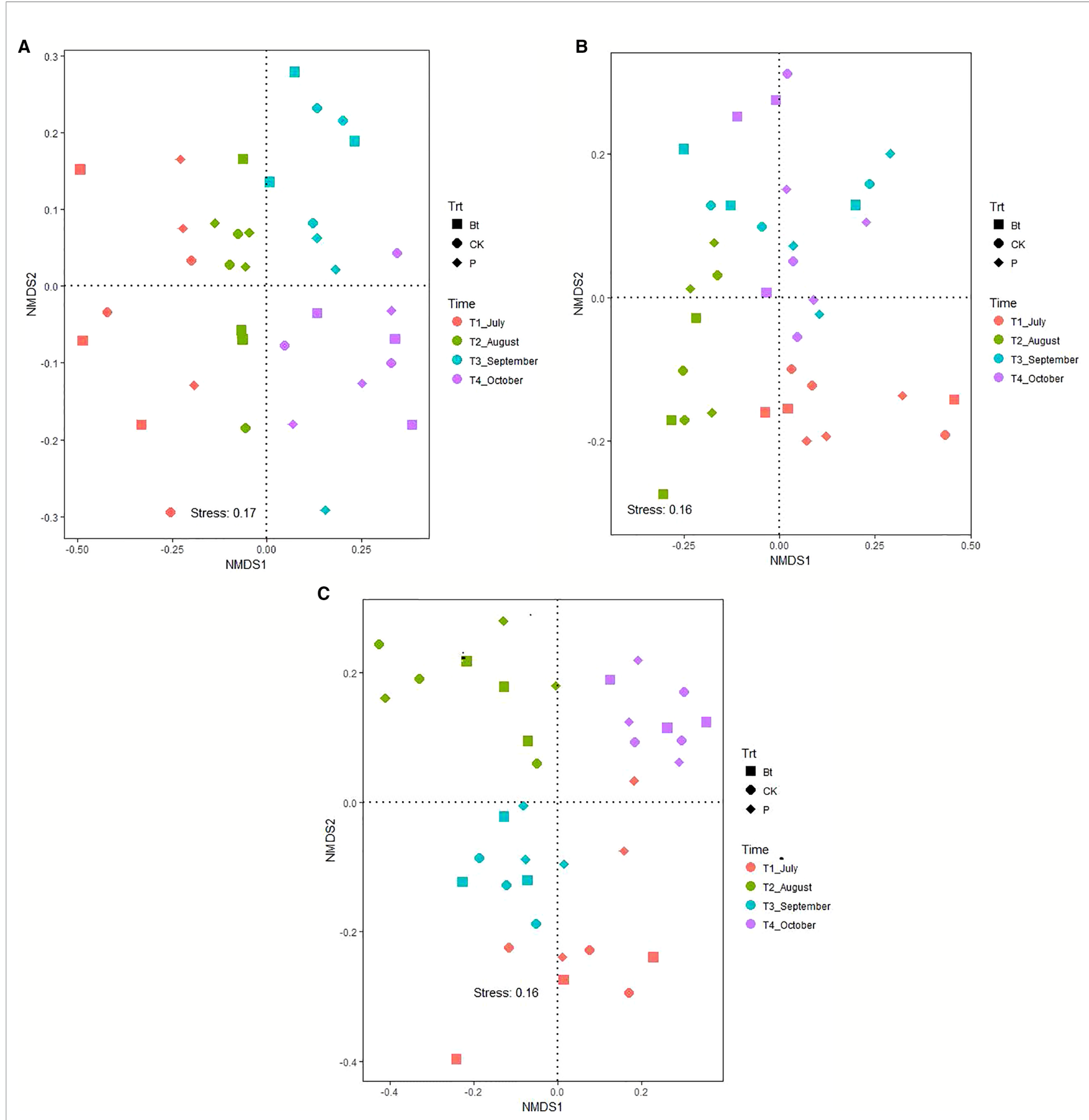

FIGURE 1 | Non-metric multidimensional scaling (NMDS) illustrating the divergence in community composition of soil nematodes in soils of rice fields under different mangement practices in 2012 (A), 2013 (B), and 2014 (C). The plot of NMDS was produced using the Bray-Curtis distance. CK: non-Bt rice without pesticide application; Bt: Bt rice without pesticide application; $\mathrm{P}$ : non-Bt rice with pesticide application.

Another studies reported that pesticide (acetochlor) application at a high dose could reduce plant parasites (Waliyar et al., 1992), the Helicotylenchus (Todd et al., 1992), the Pratylenchus in soil (Shukla and Haseeb, 1996; Zhang et al., 2010). Chen et al. (2003a) indicated that pesticide (acetochlor) impacted the numbers of total nematode and trophic groups in a Chinese soybean field. Pen-Mouratov and Steinberger (2005) found pesticides application reduced the numbers of total nematodes, fungivores, and bacterivores in a desert system. Wada and Toyota (2008) reported pesticide effectively suppressed a Pratylenchus penetrans, but had little impact on free-living nematodes in a pot test. The discrepancy across studies may relate to pesticide type, application dose, and sensitivity of nematode species. Our findings highlight that the effects 

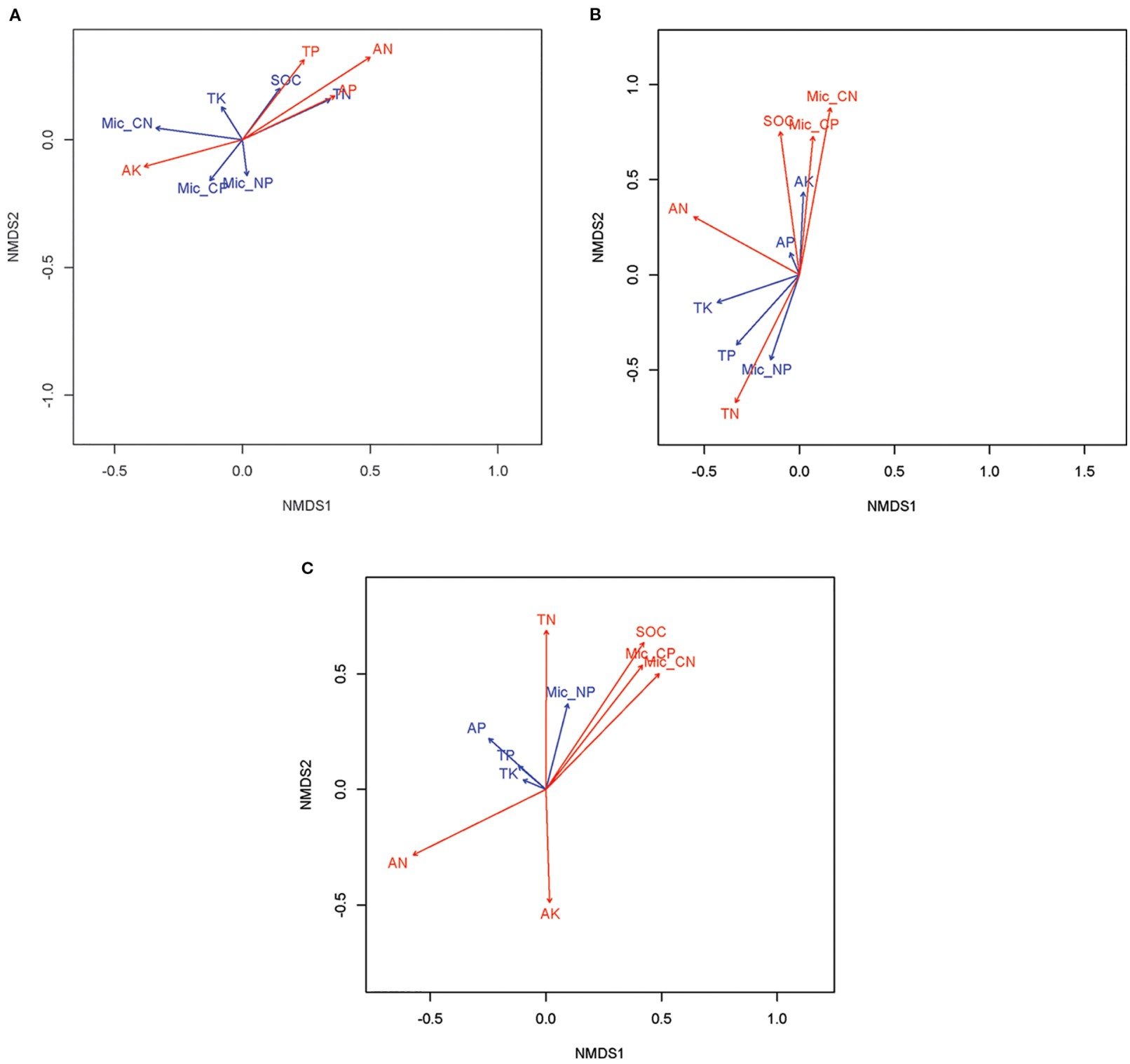

FIGURE 2 | Non-metric multidimensional scaling (NMDS) revealing the major shaping factors of soil nematode community composition in soils of rice fields under different mangement practices in 2012 (A), 2013 (B), and 2014 (C). The plot of NMDS was produced using the Bray-Curtis distance e. The red vectors show the correlation between soil attributes and soil nematode community composition are significant at $P<0.05$.

of year and sampling date were more pronounced than that of application of pesticide and Bt rice.

\section{Factors Shaping Soil Nematode Community in Rice Fields Under Paddy Condition}

Against our expectation and most studies that reporting agricultural management practice greatly impact soil nematode community (Sánchez-Moreno et al., 2009; Palomares-Rius et al., 2012), agricultural management did not change nematode community composition in the present study (Table 4). In agreement with the finding of similar issue focusing on plant parasites in Spain olive fields (Archidona-Yuste et al., 2020), soil was the following most influential factor driving nematode communities in rice paddy fields. Numerous studies suggest that nematode was closely related to soil physiochemical factors (Ferris et al., 1996; Wardle et al., 2004; Archidona-Yuste et al., 2020). For example, SOC and TN were found to be significantly associated with total nematodes abundance (Ma et al., 2018). In the present study, available N, SOC, and $\mathrm{TN}$ are important factors shaping soil nematode community in rice fields under paddy condition (Figure 2). Concerning the found close relationship between $\mathrm{N}$ and nematode, a reasonable explanation is that nematodes affect nitrogen availability both directly and indirectly (Ingham et al., 1985; Neher, 2010). 
Regarding the observed close correlation between soil nematode community and soil $\mathrm{C} / \mathrm{N}$ and microbial biomass, it is not surprisingly. After all, $\mathrm{C} / \mathrm{N}$ is a promising soil quality indicator, and it has been reported as an important influencing factor of terrestrial nematode biodiversity (Mulder and Maas, 2017).

\section{CONCLUSION}

In summary, our results give the public the actual environmental risk of $B t$ rice cultivation to soil nematodes and their associated ecological functions. All the findings support that there is no deleterious effect of $B t$ rice cultivation on soil nematode community over 3 years. Additionally, the effects of year and sampling date on nematode variables examined in rhizosphere soil were more pronounced than that of application of insecticides and $B t$ rice. Soil nutrient availability and $\mathrm{C}: \mathrm{N}$ molar ratio are the primary regulating factor of soil nematode community in rhizosphere soil of rice under paddy field condition.

\section{DATA AVAILABILITY STATEMENT}

The datasets generated for this study are available on request to the corresponding authors.

\section{REFERENCES}

Ahmad, W., and Jairajpuri, M. S. (2010). "Mononchida: the predatory soil nematodes," in Nematology Monographs and Perspectives. Eds. D. J. Hunt and R. N. Perry (Leiden-Boston, Netherlands: Brill Academic Pub.), 21-298.

Archidona-Yuste, A., Wiegand, T., Castillo, P., and Navas-Cortés, J. A. (2020). Spatial structure and soil properties shape local community structure of plantparasitic nematodes in cultivated olive trees in southern Spain. Agr. Ecosyst. Environ. 287 106688. doi: 10.1016/j.agee.2019.106688

Biederman, L. A., Boutton, T. W., and Whisenant, S. G. (2008). Nematode community development early in ecological restoration: The role of organic amendments. Soil Biol. Biochem. 40 (9), 2366-2374. doi: 10.1016/j.soilbio.2008.05.017

Bongers, T., and Bongers, M. (1998). Functional diversity of nematodes. Appl. Soil Ecol. 10 (3), 239-251. doi: 10.1016/S0929-1393(98)00123-1

Bongers, T., and Ferris, H. (1999). Nematode community structure as a bioindicator in environmental monitoring. Trends Ecol. Evol. 14 (6), 224228. doi: 10.1016/S0169-5347(98)01583-3

Bongers, T. (1994). De Nematoden van Nederland. Een Identificatietabel voor de in Nederland Aangetroffenen Zoetwater- en Bodembewonende Nematoden (Utrecht: Koninklijke Nederlandse Natuurhistorische Vereniging: John Wiley \& Sons, Ltd.), 52-408.

Bongers, T. (1999). The maturity index, the evolution of nematode life history traits, adaptive radiation and cp-scaling. Plant Soil 212 (1), 13-22. doi: 10.1023/ A: 1004571900425

Briar, S. S., Millerb, S. A., Stinnera, D., Kleinhenzc, M. D., and Grewal, P. S. (2011). Effects of organic transition strategies for peri-urban vegetable production on soil properties, nematode community, and tomato yield. Appl. Soil Ecol. 47, 8194. doi: 10.1016/j.apsoil.2010.12.001

Čerevková, A., Miklisová, D., and Cagáň, L. (2017). Effects of experimental insecticide applications and season on soil nematode communities in a maize field. Crop Prot. 92, 1-15. doi: 10.1016/j.cropro.2016.10.007

Chen, L. J., Li, Q., and Liang, W. J. (2003a). Effects of agrochemicals on nematode community structure in a soybean field. Bull. Environ. Contam. Toxicol. 71, 755-760. doi: 10.1007/s00128-003-0196-9

\section{AUTHOR CONTRIBUTIONS}

BY, FC and FG designed the experiment. QC, XL, YL and FC did the experiment. BY, WQ, and $\mathrm{LH}$ analyzed the data. All the authors wrote and improved the manuscript.

\section{FUNDING}

This study was jointly supported by the National Natural Science Foundation of China (Grant number: 31400360), the State Scholarship Fund of the Chinese Scholarship Council (grant number: 201604910484), and the Special Program for New Transgenic Variety Breeding of the Ministry of Science and Technology, China (2016ZX08012005). The authors thank professor Carolina Escobar and two anonymous reviewers for their critical and constructive suggestions of an earlier draft.

\section{SUPPLEMENTARY MATERIAL}

The Supplementary Material for this article can be found online at: https://www.frontiersin.org/articles/10.3389/fpls.2020.00088/ full\#supplementary-material

Chen, M., Ye, G., Hu, C., Tu, J., and Datta, S. (2003b). Effect of transgenic Bt rice on dispersal of planthoppers and leafhoppers as well as their egg parasitic wasps. J. Zhejiang Univ. (Agric. Life Sci.) 29, 29-33.

Chen, M., Shelton, A., and Ye, G. Y. (2011). Insect-resistant genetically modified rice in China: from research to commercialization. Annu. Rev. Entomol. 56, 81-101. doi: 10.1146/annurev-ento-120709-144810

Chen, Q., Yang, B., Liu, X., Chen, F., and Ge, F. (2017a). Long-term cultivation of $\mathrm{Bt}$ rice expressing the $c r y 1 A b / A c$ gene reduced phytoparasitic nematode abundance but did not affect other nematode parameters in paddy fields. Sci. Total Environ. 607, 463-474. doi: 10.1016/j.scitotenv.2017.06.225

Chen, X., Liu, T., Li, X., Li, H., Chen, F., Liu, M., et al. (2017b). Soil nematode community varies between rice cultivars but is not affected by transgenic Bt rice expressing crylAb or crylAb/crylAc. Biol. Fert. Soils 53 (5), 501-509. doi: 10.1007/ s00374-017-1211-3

Ferris, H., Venette, R. C., and Lau, S. S. (1996). Dynamics of nematode communities in tomatoes grown in conventional and organic farming systems, and their impact on soil fertility. Appl. Soil Ecol. 3, 161-175. doi: 10.1016/0929-1393(95)00071-2

Frutos, R., Rang, C., and Royer, M. (1999). Managing insect resistance to plants producing Bacillus thuringiensis Toxins. Crit. Rev. Biotechnol. 19 (3), 227-276. doi: 10.1080/0738-859991229251

Godefroid, M., Delaville, L., Marie-Luce, S., and Quénéhervé, P. (2013). Spatial stability of a plant-feeding nematode community in relation to macro-scale soil properties. Soil Biol. Biochem. 57, 173-181. doi: 10.1016/j.soilbio.2012.06.019

Gould, F. (2000). Testing Bt refuge strategies in the field. Nat. Biotechnol. 18, 266-267. doi: $10.1038 / 73693$

Griffiths, B., Caul, S., Thompson, J., Birch, A., Scrimgeour, C., Andersen, M. N., et al. (2005). A comparison of soil microbial community structure, protozoa and nematodes in field plots of conventional and genetically modified maize expressing the Bacillus thuringiens is CrylAb toxin. Plant Soil 275 (1), 135-146. doi: 10.1007/s11104-005-1093-2

Höss, S., Nguyen, H., Menzel, R., Pagel-Wieder, S., Miethling-Graf, R., Tebbe, C., et al. (2011). Assessing the risk posed to free-living soil nematodes by a genetically modified maize expressing the insecticidal Cry3Bb1 protein. Sci. Total Environ. 409 (13), 2674-2684. doi: 10.1016/j.scitotenv.2011.03.041 
Höss, S., Reiff, N., Ottermanns, R., Pagel-Wieder, S., Dohrmann, A. B., Tebbe, C. C., et al. (2015). Risk assessment of the cultivation of a stacked Bt-maize variety (MON89034× MON88017) for nematode communities. Soil Biol. Biochem. 91, 109-118. doi: 10.1016/j.soilbio.2015.08.022

Halwart, M. (2008). Biodiversity, nutrition and livelihoods in aquatic rice-based ecosystems. Biodiversity 9 (1-2), 36-40. doi: 10.1080/14888386.2008.9712879

High, S. M., Cohen, M. B., Shu, Q. Y., and Altosaar, I. (2004). Achieving successful deployment of Bt rice. Trends Plant Sci. 9 (6), 286-292. doi: 10.1016/ j.tplants.2004.04.002

Huang, J., Hu, R., Rozelle, S., and Pray, C. (2005). Insect-resistant GM rice in farmers' fields: assessing productivity and health effects in China. Science 308 (5722), 688-690. doi: 10.1126/science.1108972

Icoz, I., and Stotzky, G. (2008). Fate and effects of insect-resistant Bt crops in soil ecosys-tems. Soil Biol. Biochem. 40, 559-586. doi: 10.1016/j.soilbio. 2007.11.002

Ingham, R. E., Trofymow, J. A., Ingham, E. R., and Coleman, D. C. (1985). Interactions of bacteria, fungi, and their nematode grazers: effects on nutrient cycling and plant growth. Ecol. Monogr. 55, 119-140. doi: 10.2307/1942528

Kaplan, M., and Noe, J. P. (1993). Effects of chiken-excrement amendments on Medloidogyne arenaira. J. Nematol. 25 (1), 71-77. doi: 10.1006/jipa.1993.1042

Karuri, H., Amata, R., Amugune, N., and Waturu, C. (2013). Effect of Bt cotton expressing $\mathrm{Cry} 1 \mathrm{Ac}$ and $\mathrm{Cry} 2 \mathrm{Ab} 2$ protein on soil nematode community assemblages in Mwea, Kenya. J. Anim. Plant Sci. 19 (1), 2864-2879.

Li, X., and Liu, B. (2013). A 2-year field study shows little evidence that the longterm planting of transgenic insect-resistant cotton affects the community structure of soil nematodes. PloS One 8 (4), e61670. doi: 10.1371/ journal.pone. 0061670

Li, G., Wang, Y., Liu, B., and Zhang, G. (2014). Transgenic Bacillus thuringiensis (Bt) rice is safer to aquatic ecosystems than its non-transgenic counterpart. PloS One 9 (8), e104270. doi: 10.1371/journal.pone.0104270

Liang, W., Lou, Y., Li, Q., Zhong, S., Zhang, X., and Wang, J. (2009). Nematode faunal response to long-term application of nitrogen fertilizer and organic manure in Northeast China. Soil Biol. Biochem. 41 (5), 883-890. doi: 10.1016/ j.soilbio.2008.06.018

Liu, Y., Li, J., Stewart, C. N., Luo, Z., and Xiao, N. (2015). The effects of the presence of Bt-transgenic oilseed rape in wild mustard populations on the rhizosphere nematode and microbial communities. Sci. Total Environ. 530, 263-270. doi: 10.1016/j.scitotenv.2015.05.073

Liu, T., Whalen, J. K., Ran, W., Shen, Q. R., and Li, H. X. (2016). Bottom-up control of fertilization on soil nematode communities differs between crop management regimes. Soil Biol. Biochem. 95, 198-201. doi: 10.1016/ j.soilbio.2016.01.005

Liu, L., Wu, L., and Eickhorst, T. (2018a). Accumulation of Cry1Ab/Ac proteins released from transgenic Bt-rice in the rhizosphere of a paddy soil. Rhizosphere 6, 39-46. doi: 10.1016/j.rhisph.2018.02.002

Liu, T., Chen, X., Qi, L., Chen, F., Liu, M., and Whalen, J. K. (2018b). Root and detritus of transgenic Bt crop did not change nematode abundance and community composition but enhanced trophic connections. Sci. Total Environ. 644, 822-829. doi: 10.1016/j.scitotenv.2018.07.025

$\mathrm{Lu}, \mathrm{B}$. R., and Snow, A. A. (2005). Gene flow from genetically modified rice and its environmental consequences. AIBS Bull. 55 (8), 669-678. doi: 10.1641/00063568(2005)055[0669:GFFGMR]2.0.CO;2

Lu, Y., Wu, K., Jiang, Y., Guo, Y., and Desneux, N. (2012). Widespread adoption of Bt cotton and insecticide decrease promotes biocontrol services. Nature 487 (7407), 362-365. doi: 10.1038/nature11153

Ma, Q., Yu, H., Liu, X., Xu, Z., Zhou, G., and Shi, Y. (2018). Climatic warming shifts the soil nematode community in a desert steppe. Clim. Change 150 (3-4), 243-258. doi: 10.1007/s10584-018-2277-0

Manachini, B., and Lozzia, G. (2002). First investigations into the effects of Bt corn crop on Nematofauna. Bollettino di Zool. Agrar. e di Bachicoltura 34 (1), 85-96.

Mulder, C., and Maas, R. (2017). Unifying the functional diversity in natural and cultivated soils using the overall body-mass distribution of nematodes. $B M C$ Ecol. 17, 36. doi: 10.1186/s12898-017-0145-9

Naira, A., and Ngouajiob, M. (2012). Soil microbial biomass, functional microbial diversity, and nematode community structure as affected by cover crops and compost in an organic vegetable production system. Appl. Soil Ecol. 58, 45-55. doi: 10.1016/j.apsoil.2012.03.008
Neher, D. A., Muthumbi, A. W., and Dively, G. P. (2014). Impact of coleopteranactive Bt corn on non-target nematode communities in soil and decomposing corn roots. Soil Biol. Biochem. 76, 127-135. doi: 10.1016/j.soilbio.2014.05.019

Neher, D. A. (2001). Role of nematodes in soil health and their use as indicators. J. Nematol. 33 (4), 161-168.

Neher, D. A. (2010). Ecology of plant and free-living nematodes in natural and agricultural soil. Annu. Rev. Phytopathol. 48, 371-394. doi: 10.1146/annurevphyto-073009-114439

Olsen, S. R., and Sommers, L. E. (1982). "Phosphorus.” in: Methods of soil analysis part 2-chemical and microbiological properties, American Society of Agronomy. Eds. A. L. Page, R. H. Miller, and D. R. Keeney (Madison, WI: Soil Science Society of America), 403-430.

Palomares-Rius, J. E., Castillo, P., Montes-Borrego, M., Müller, H., and Landa, B. B. (2012). Nematode community populations in the rhizosphere of cultivated olive differs according to the plant genotype. Soil Biol. Biochem. 45, 168-171. doi: 10.1016/j.soilbio.2011.11.009

Pen-Mouratov, S., and Steinberger, Y. (2005). Responses of nematode community structure to pesticide treatments in an arid ecosystem of the Negev Desert. Nematology 7, 179-191. doi: 10.1163/1568541054879476

R_Core_Team (2016). R: a Lenguage and Environment for Statistical Computing (Vienna, Austria: R Foundation for Statistical Computing).

Ruf, A., Beylich, A., Blick, T., Büchs, W., Glante, F., Höss, S., et al. (2013). Soil organisms as an essential element of a monitoring plan to identify the effects of GMO cultivation. Requirements-methodology-standardisation. BioRisk 8, 73-87. doi: $10.3897 /$ biorisk.8.3255

Sánchez-Moreno, S., Nicola, N. L., Ferris, H., and Zalom, F. G. (2009). Effects of agricultural management on nematode-mite assemblages: soil food web indices as predictors of mite community composition. Appl. Soil Ecol. 41, 107-117. doi: 10.1016/j.apsoil.2008.09.004

Saxena, D., Flores, S., and Stotzky, G. (1999). Insecticidal toxin in root exudates from Bt corn. Nature 402, 480. doi: 10.1038/44997

Shukla, P. K., and Haseeb, A. (1996). Effectiveness of some nematicides and oil cakes in the management of Pratylenchus thornei on Mentha citrate, M. piperita and $M$. spicata. Bioresour. Technol. 57, 307-310. doi: 10.1016/S0960-8524(96)00084-3

Tabashnik, B. E., and Carriere, Y. (2017). Surge in insect resistance to transgenic crops and prospects for sustainability. Nat. Biotechnol. 35 (10), 926-935. doi: $10.1038 /$ nbt. 3974

Tapp, H., Calamai, L., and Stotzky, G. (1994). Adsorption and binding of the insecticidal proteins from Bacillus thuringiensis subsp. kurstaki and subsp. tenebrionis on clay minerals. Soil Biol. Biochem. 26, 663-679. doi: 10.1016/ 0038-0717(94)90258-5

Todd, T. C., James, S. W., and Seastedt, T. R. (1992). Soil invertebrate and plant responses to mowing and carbofuran application in a North American tallgrass prairie. Plant Soil 144, 117-124. doi: 10.1007/BF00018852

Tu, J., Zhang, G., Datta, K., Xu, C., He, Y., Zhang, Q., et al. (2000). Field performance of transgenic elite commercial hybrid rice expressing Bacillus thuringiensis $\delta$ endotoxin. Nat. Biotechnol. 18 (10), 1101-1104. doi: 10.1038/80310

Wada, S., and Toyota, K. (2008). Effect of three organophosphorous nematicides on non-target nematodes and soil microbial community. Microbes Environ. 23, 331-336. doi: 10.1264/jsme2.ME08534

Waliyar, F., Ndunguru, B. J., Sharma, S. B., and Bationo, A. (1992). Effect of liming and carbofuran on groundnut yield in sandy soils in Niger. Fertil. Res. 33, 203-208. doi: 10.1007/BF01050875

Walker, T. W., and Adams, A. F. R. (1958). Studies on soil organic matter: 1. Influence of phosphorus contents of parent materials on accumulations of carbon, nitrogen, sulfur, and organic phosphorus in grassland soils. Soil Sci. 85, 307-318. doi: 10.1097/00010694-195806000-00004

Wang, H., Ye, Q., Gan, J., and Wu, L. (2007). Biodegradation of Cry1 Ab protein from Bt transgenic rice in aerobic and flooded paddy soils. J. Agr. Food Chem. 55 (5), 1900-1904. doi: 10.1021/jf062924x

Wang, Y., Zhang, G., Du, J., Liu, B., and Wang, M. (2010). Influence of transgenic hybrid rice expressing a fused gene derived from cryl $\mathrm{Ab}$ and crylAc on primary insect pests and rice yield. Crop Prot. 29 (2), 128-133. doi: 10.1016/j.cropro.2009.10.004

Wang, Y., Huang, J., Hu, H., Li, J., Liu, B., and Zhang, G. (2013). Field and laboratory studies on the impact of two Bt rice lines expressing a fusion protein Cryl Ab/1Ac on aquatic organisms. Ecotoxicol. Environ. Saf. 92, 87-93. doi: 10.1016/j.ecoenv.2013.02.018 
Wang, J. M., Chen, X. P., Liang, Y. Y., Zhu, H. J., Ding, J. T., and Peng, Y. F. (2014). Influence of transgenic rice expressing a fused Cry $1 \mathrm{Ab} / 1 \mathrm{Ac}$ protein on frogs in paddy fields. Ecotoxicology 23 (9), 1619-1628. doi: 10.1007/s10646-014-1301-Z

Wang, X., Liu, Q., Meissle, M., Peng, Y., Wu, K., Romeis, J., et al. (2018). Bt rice could provide ecological resistance against nontarget planthoppers. Plant Biotechnol. J. 16 (10), 1748-1755. doi: 10.1111/pbi.12911

Wardle, D. A., Bardgett, R. D., Klironomos, J. N., Setälä, H., Van Der Putten, W. H., and Wall, D. H. (2004). Ecological linkages between aboveground and belowground biota. Science 304, 1629-1633. doi: 10.1126/science.1094875

Yang, B., Chen, H., Liu, X., Ge, F., and Chen, Q. (2014). Bt cotton planting does not affect the community characteristics of rhizosphere soil nematodes. Appl. Soil Ecol. 73, 156-164. doi: 10.1016/j.apsoil.2013.09.001

Yeates, G. W., Bongers, T. D., De Goede, R., Freckman, D., and Georgieva, S. (1993). Feeding habits in soil nematode families and genera-an outline for soil ecologists. J. Nematol. 25 (3), 315-331.

Yeomans, J. C., and Bremner, J. M. (1988). A rapid and precise method for routine determination of organic carbon in soil 1. Commun. In Soil Sci. Plant Anal. 19 (13), 1467-1476. doi: 10.1080/00103628809368027
Zhang, J. N., Li, Q., and Liang, W. J. (2010). Effect of acetochlor and carbofuran on soil nematode communities in a Chinese soybean field. Afr. J. Agr. Res. 5 (20), 2787-2794. doi: 10.1016/S1671-2927(09)60248-0

Zwahlen, C., Hilbeck, A., Howald, R., and Nentwig, W. (2003). Effects of transgenic Bt corn litter on the earthworm. Mol. Ecol. 12, 1077-1086. doi: 10.1046/j.1365-294X.2003.01799.x

Conflict of Interest: The authors declare that the research was conducted in the absence of any commercial or financial relationships that could be construed as a potential conflict of interest.

Copyright (c) 2020 Yang, Chen, Liu, Chen, Liang, Qiang, He and Ge. This is an openaccess article distributed under the terms of the Creative Commons Attribution License (CC BY). The use, distribution or reproduction in other forums is permitted, provided the original author(s) and the copyright owner(s) are credited and that the original publication in this journal is cited, in accordance with accepted academic practice. No use, distribution or reproduction is permitted which does not comply with these terms. 